\title{
Cancer TNM Finding
}

National Cancer Institute

\section{Source}

National Cancer Institute. Cancer TNM Finding. NCI Thesaurus. Code C48232.

A cancer finding in the TNM system that is relevant to the diagnosis of cancer. 